\title{
Teatr, media i ekranizacje filmowe jako sposoby włączania osób niepełnosprawnych intelektualnie do przestrzeni społecznej
}

\author{
Theatre, media and film adaptations as measures \\ of implementation of intellectually disabled people \\ into social area
}

\begin{abstract}
Streszczenie:
Artykuł ma za zadanie zaprezentowanie sposobu włączenia osób niepełnosprawnych intelektualnie do przestrzeni społecznej. Zostały tu ukazane działania teatrów. W instytucjach tych na scenie dokonuje się integracja osób niepełnosprawnych intelektualnie z osobami pełnosprawnymi. Widoczny jest także wpływ teatroterapii na ich poczucie godności, wartościowości, zadowolenia z życia. Celem jest ukazanie oddziaływań mediów i produkcji filmowych na włączenie osób niepełnosprawnych do społeczeństwa.

Słowa kluczowe: integracja osób niepełnosprawnych intelektualnie z osobami pełnosprawnymi; przestrzeń społeczna; teatroterapia; produkcje filmowe z osobami niepełnosprawnymi intelektualnie

Abstract:

This article is to present the manner in which intellectually disabled people are implement into social area. Functioning of theatres have been covered herein. In this institutions effectuates integration of intellectually disabled people with abled ones. Theatre Therapy allows to build their dignity sense, worthiness and satisfaction from life. The aim is to show the effect media and film productions has on the implementation of disabled people into society.
\end{abstract}


Ewelina Romianowska - Teatr, media i ekranizacje...

Keywords: integration of intellectually disabled people with abled; Social area; Theatre Therapy; film productions with intellectually disabled people.

\section{W świecie integracji osób niepełnosprawnych z osobami pełnosprawnymi}

(...) Człowieku, gdy los ze mną zetknie Cię

i w przyszłości poznamy się, nie obawiaj się wtedy mnie.

Podejdź do mnie, jak podchodzisz do drugiego człowieka nie uciekaj i przywitaj ze mną się.

A kiedy przełamiemy do siebie lody swe

ja, jak zawsze, zniżę dla Ciebie człowieku, się.

(...) Spójrz na mnie

ja też jestem jak Ty-człowiek, taki sam

tylko mniejszą sprawność od Ciebie, człowieku, mam.

Spójrz na mnie

I prosto w oczy na pytanie odpowiedz mi,

- Czy w moim wyglądzie brakuje czegoś mi?

a nawet gdyby członków było mi brak,

to moja odpowiedź brzmiałaby "tak” -

bez członków też można żyć,

nie musisz całym i zdrowym być,

aby człowiekiem nazywać się.

I tak naprawdę, to nie niezależnie od tego

czy jesteś sprawny, czy nie,

to nie wystarczy człowiekiem urodzić się.

trzeba jeszcze człowiekiem być,

aby łatwiej wspólnie było NAM żyć1

Niniejszy artykuł ma za zadanie zaprezentowanie sposobu włączenia osób niepełnosprawnych intelektualnie do przestrzeni społecznej poprzez teatr na przykładzie teatrów, w których na scenie dokonuje się integracja osób niepełnosprawnych intelektualnie z osobami pełnosprawnymi, a także ukazanie oddziaływań mediów i produkcji filmowych na włączenie osób niepełnosprawnych do społeczeństwa.

1 http://www.duszki.pl/poogladaj_poczytaj/swiadectwa/artykul_o_gosi.html [dostęp: 20.12.2016]. 
Rozważania na temat udziału osób niepełnosprawnych w społeczeństwie, relacji interpersonalnej, jaka występuje między osobami niepełnosprawnymi a pełnosprawnymi, rozpoczęłam od przytoczenia wiersza Małgorzaty Janiszewskiej. Jest ona kobietą niepełnosprawną, mieszkanką Domu Społecznego w Kwidzynie, zaś wiersze zaczęła pisać w latach 90-tych. Opisuje w nich zmagania, jakim musi sprostać osoba niepełnosprawna, ale także odnosi się do chwil radości, jakie spotkały ją w życiu. Twórczość tej poetki jest warta przeczytania. W swej poezji przedstawia także relacje, jakie wytwarzają się w przestrzeni społecznej między członkami społeczeństwa. Przytoczony wiersz jest apelem do osób pełnosprawnych o przyjęcie osób niepełnosprawnych do swojego otoczenia, o nieobawianie się osób niepełnosprawnych i ich fizyczności. Każdy człowiek jest taki sam, każdy pragnie żyć, dąży do relacji z drugą osobą i spełniania się w życiu.

Człowiek jest istotą społeczną, uwikłaną w ciąg relacji interpersonalnych, bez których ludzka egzystencja nie miałaby sensu. Celem artykułu jest ukazanie, jak ważny jest teatr, film i media w drodze ku włączeniu osób niepełnosprawnych intelektualnie do społeczeństwa. Przestrzeń społeczna, w której żyją osoby zarówno pełnosprawne, jak i niepełnosprawne, jest niezwykle ważna. Liczni autorzy na kartach swoich książek starali się ukazać oddziaływanie tej przestrzeni na człowieka, a także kreowanie tej samej przestrzeni przez tegoż samego człowieka. Przestrzeń społeczna definiowana jest przez Katarzynę Parys następująco:

(...) przestrzeń społeczna jest zróżnicowana, wielokulturowa, wieloelementowa. Tworzą ją jednostki, które wykazują szereg różnic i podobieństw. Ponieważ w przestrzeni tej nie ma dwóch identycznych, tożsamych we wszystkich zakresach osób, zasadne byłoby traktowanie każdej osoby w sposób indywidualny².

Zatem społeczeństwo tworzą jednostki różniące się od siebie wieloma cechami, mające inny bagaż doświadczeń; mogą to być osoby

\footnotetext{
2 K. Parys, Przestrzeń społeczna, [w:] S. Olszewski, K. Parys, M. Trojańska, Przestrzenie życia osób z niepełnosprawnością, Wydawnictwo Kraków 2012, s. 89.
} 
Ewelina Romianowska - Teatr, media i ekranizacje...

pełnosprawne bądź niepełnosprawne, które pod wieloma aspektami podobne do siebie.

Integracja społeczna osób niepełnosprawnych intelektualnie z osobami pełnosprawnymi to działania wielopłaszczyznowe. To tworzenie relacji międzyludzkich między tymi osobami. Wpływając na rozwój społeczny uczestników tych relacji i ich rozwój emocjonalny, pozwala wyzbyć się lęku, uprzedzeń, które wielokrotnie są wynikiem tworzonych w społeczeństwie stereotypów na temat osób niepełnosprawnych intelektualnie. Jak mówi Iwona Rudek:

(...) codzienne bytowanie, współpraca w wielu dziedzinach życia, współdziałanie i współuczestnictwo realizacji zwykłych sytuacji, wspólne podejmowanie decyzji i rozwiązywanie problemów dają możliwość wchodzenia w bliskie relacje interpersonalne. Sprzyja to nawiązywaniu kontaktów społecznych, zawieraniu znajomości, rozwijaniu przyjaźni, w wyniku, których rodzą się silne więzi emocjonalne ${ }^{3}$.

Takie interakcje są niezwykle potrzebne osobom niepełnosprawnym, by poczuć się jak pełnoprawni członkowie przestrzeni, w której żyją. Każdy człowiek, spotykając się z nowym doświadczeniem, może być przestraszony, niepewny, ale to doświadczenie może także przyczynić się do wewnętrznej zmiany. U osób niepełnosprawnych może ono przyczynić się do zwiększenia otwartości i większej pewności siebie w stawianiu sobie celów. Jednakże taka integracja ma także i swych przeciwników. Uważają oni, iż:

(...) integracja społeczna jednostek niepełnosprawnych napotyka jednak na drodze realizacji wiele przeszkód. Są to utrudnienia wynikające z codzienności życia społecznego, rozumienia wartości uznanych za obowiązujące przez dalsze i otoczenie, jak i również i takie, które utrudniają proces edukacji i młodzieży niepełnosprawnej. Negatywne postawy ujawnianie wobec osób niepełnosprawnych nazwane są barierami społecznymi .

3 I. Rudek, Podstawy wobec osób niepełnosprawnych jako wyznacznik działań integracyjnych, [w:] Z. Kazanowski, D. Osik-Chudowolska (red.), Integracja osób niepetnosprawnych w edukacji i interakcjach społecznych, Lublin 2003, s. 70.

4 Ibidem. 
Takie bariery powodują zmniejszenie aktywności w grupie, zamykanie się członków tej grupy na świat zewnętrzny, niedostrzeganie plusów otaczającej rzeczywistości. Bowiem świat zewnętrzny stwarza im blokadę, której nie są w stanie sami pokonać. Dlatego tak ważna jest rewalidacja osób niepełnosprawnych poprzez integrację z osobami pełnosprawnymi. Aktywność społeczna osób niepełnosprawnych jest niezwykle istotna, ponieważ właśnie dzięki niej nie tylko pokonują swoje słabości, ale także pokazują światu, że są takimi samymi członkami społeczności, jak osoby pełnosprawne.

Artykuł ten ma na celu ukazanie, jak ważna jest aktywność osób niepełnosprawnych $\mathrm{w}$ łamaniu przez nich różnych barier, przede wszystkim swoich wewnętrznych słabości; w ukazywaniu swoich mocnych stron oraz talentu. Teatroterapia, film i media to także sposoby integracji osób niepełnosprawnych z pełnosprawnymi.

\section{Włączenie do przestrzeni społecznej poprzez teatr}

Teatr od zarania dziejów i zachwycał, i wzbudzał wiele kontrowersji. Jego początków można szukać w obrzędach religijnych:

(...) teatr rozwinął się z obrzędów religijnych, a konkretniej z procesji ku czci Dionizosa. Uczestnicy tych obrzędów w wyniku długotrwałego procesu podzielili się na aktorów i na widzów, i tak powstał teatr5.

Autorzy poruszali także kwestię zbawczej dla duszy roli teatru. Już w starożytnej Grecji uważano, że jest on źródłem szczęścia. A czy nie o to w życiu chodzi, by być szczęśliwym? Dzisiejszy teatr cechuje się różnorodnością form, metod, działań. Ponadto przyczynia się do oddziaływań kompensacyjnych, terapeutycznych i profilaktycznych:

„teoria terapii teatrem i jej praktyka dotyczy oddziaływań kompensacyjnych, terapeutycznych czy profilaktycznych, w których uczestniczy zarówno osoba

${ }^{5}$ A. Stefańska, Teatroterapia jako metoda kształtowania poczucia godności u osób niepełnosprawnych intelektualnie, Poznań 2012, s. 43. 
Ewelina Romianowska - Teatr, media i ekranizacje...

wspomagana, która przejawia trudności lub zaburzenia w sferze psychicznej, somatycznej lub społecznej, jak i osoba wspomagająca"6.

Teatrolodzy osadzają teatr $\mathrm{w}$ szerokiej działalności człowieka. Przyczynia się on do kształtowania własnej wartości. Agnieszka Piasecka wspomina także o oczyszczeniu, jakie dokonuje się poprzez teatr:

(...) człowiek dzięki teatrowi podlega swoistej terapii- oczyszczeniu. Uczestnictwo $\mathrm{w}$ teatrze zawsze jest wielkim przeżyciem; przez emocjonalne zaangażowanie się weń, zapomnienie się w rytuale, człowiek przezwycięża lęk. Jego życie duchowe staje się bogatsze. Dzięki teatrowi człowiek poznaje świat i przekształca go, świadomie lub nieświadomie poznaje siebie, zagłębia się w swoją psychikę i rytuały nią rządzące ${ }^{7}$.

Człowiek podczas gry na scenie zagłębia się w swoje uczucia, pragnie okazania z siebie czegoś więcej, czegoś, co sprawiłoby, że grana postać stanie się prawdziwa, realna dla widza. Aktor uzewnętrznia swoje uczucia, sam siebie poznaje na nowo. Działania, jakie dokonywane są poprzez grupę aktorów, ich współdziałanie ze sobą, poleganie na sobie, integrują członków danej grupy, pozwalają zapomnieć o lęku i wszelkich granicach.

Współczesny teatr jest otwarty na osoby niepełnosprawne, zarówno na aktorów, jak i widzów niepełnosprawnych, w ten sposób powstaje "teatr bez barier". Scena nie jest zamknięta na niepełnosprawnego aktora, daje mu szansę zaistnienia, a co więcej spełnienia swoich pragnień, spełnienia siebie. Osoby te nabywają umiejętności przydatnych w codziennym funkcjonowaniu. Alicja Mojko, terapeutka, wypowiada się o konieczności zajęć teatralnych następująco: „zajęcia tea-

${ }^{6}$ M. Stańko, Arteterapia, mechanizmy działania z perspektywy neuropsychologii, „Psychoterapia” 2009, nr 2(149), s. 30.

${ }^{7}$ A. Piasecka, Terapeutyczna funkcja teatru. Między teoriq a praktyka, [w:] I. Jajte (red.), Terapia i teatr. Wokół problematyki teatru ludzi niepełnosprawnych, Łódź 1996, s. 51. 
tralne prowadzę ze wszystkimi i uważam, że one są jakby wszystkim bardzo potrzebne" 8 . I kontynuuje

(...) nie jestem ani psychologiem, ani terapeutą i na szczęście nie wiem, co oni mogą, a czego nie mogą, co jest możliwe, a co nie jest możliwe. Ponieważ tego nie wiem, staram się proponować różne rzeczy i w zależności od tego czy to chwyta, czy nie chwyta, to robimy 9 .

Często niepełnosprawni są wrzucani do jednego worka zmartwień, bólu i wszelkich ograniczeń, które niemalże wykluczają ich z wszelkiej aktywności, dzięki której mogliby się rozwijać. Tak naprawdę bardzo duża grupa osób niepełnosprawnych intelektualnie to osoby, które znają swoje ograniczenia, ale także wiedzą, że chcą coś osiągnąć. Wiedzą, co im sprawia radość i chcą to robić.

Współczesny teatr zmienił swe oblicze, porusza kwestie dotyczące otaczającej rzeczywistości, daje szansę zatrudnienia osobom niepełnosprawnym:

(...) współczesny teatr próbuje rozbić tradycyjne stereotypy myślenia o świecie i egzystencji człowieka. Jego twórcy starają się stwarzać okazje, aby człowiek przestał być sam. Tworząc sytuacje zmuszające nie widza, ale właśnie uczestnika spektaklu do osobistej refleksji jak żyć? ${ }^{10}$.

Teatr, to nie tylko część świata kultury, to także część przestrzeni społecznej. Bowiem daje wskazówki nie tylko aktorom, ale także widzom, jak żyć, jakim szlakiem pójść, by uczynić swoje życie wartościowym, by nie zatracić ducha człowieczeństwa. Teatr nie pozwala na bycie samemu, on wychodzi naprzeciw samotności, zatapiając się emocjonalnie w piękno sztuki. Podążając w tym kierunku, można dostrzec, iż twórczość artystyczna pozwala usuwać z życia wszelkie kryzysy i zwątpienia egzystencjalne, doprowadzając do osiągnięcia równowagi psychicznej ${ }^{11}$. To z kolei potwierdza rolę katarsis, jaką przypi-

${ }^{8}$ A. Andrzejczuk, Terapeutyczne aspekty aktywności teatralnej osób z niepełnosprawnościq, [w:] M. Gliniecki i L. Maksymowicz (red.), Teatr. Terapia - Edukacja Asertywność - Twórczość - Rozwój, Słupsk 2004, s. 119.

9 Ibidem.

${ }^{10}$ A. Stefańska, Teatroterapia jako metoda..., op. cit., s. 44.

11 Ibidem. 
Ewelina Romianowska - Teatr, media i ekranizacje...

suje się teatrowi, bowiem to dzięki niej aktor oczyszcza się ze swych zmartwień, kryzysów, otrzymując od sztuki równowagę psychiczną.

Teatroterapia to niezwykła forma rewalidacji, a ponad wszystko:

(...) teatroterapia to bardzo oryginalna forma rewalidacji osób niepełnosprawnych intelektualnie. Dostarcza uczestnikom różnorodnych bodźców terapeutycznych przyczyniających się do: zmniejszenia nadpobudliwości emocjonalnej, pomniejszania blokad psychicznych, kontrolowania zachowań, wyrażania emocji przez ciało, budowania relacji w grupie. W konsekwencji ułatwia integrację społeczną ${ }^{12}$.

Przez półtora roku prowadziłam badania, zakończone napisaniem w 2016 r. pracy licencjackiej pt. „Koncepcja bycia aktorką w rozumieniu kobiet z niepełnosprawnością intelektualną". Prowadziłam je metodą etnograficzną próby celowej pięciu kobiet z warsztatów teatralnych w Toruniu. Jedną z nich była 54-letnia kobieta z zespołem Downa i niepełnosprawnością intelektualną w stopniu umiarkowanym. Jest to kobieta, która walczy ze swą niepełnosprawnością, a światu pragnie pokazać siebie i swe umiejętności od najlepszej strony. Pragnie, by kojarzoną ją przez to, czym się zajmuje, a jest aktorką warsztatów teatralnych, sama także dąży do prowadzenia takich warsztatów Pisze spektakle, rozdziela role, robi dekoracje. W swoich sztukach jest aktorką, reżyserką, suflerem. Bez problemu uczy się tekstu na pamięć. Ma kilkadziesiąt zapisanych zeszytów ze sztukami teatralnymi własnego autorstwa. Marzy, aby pokazać światu, iż jeśli ma się pasję, to można wszystko osiągnąć. Podczas wywiadu dowiedziałam się od niej, jak bardzo ważne są zajęcia teatralne dla osób niepełnosprawnych intelektualnie i jak wiele zyskują dzięki nim:

Dla mnie to jest ogromna satysfakcja, że ja mogę wyjść na scenę i pokazać, że potrafię zagrać w przedstawieniu. Moim zdaniem to jest, że dzięki temu, że jest koło teatralne osoba niepełnosprawna może udowodnić, że nie jest gorsza wcale od zdrowej osoby [z wywiadu].

12 M. Bliska, R. Golanko, Teatroterapia jako jedna z form rewalidacji osób niepetnosprawnych intelektualnie,[w:] J. Bergier, Z. Kubiańska (red.), Kultura i rekreacja ruchowa w integracji osób niepełnosprawnych, Biała Podlaska 2006, s. 176. 
Kobiety z warsztatów teatralnych, które brały udział w prowadzonym przeze mnie badaniu, dążą do normalności w swoim życiu. Poprzez występy na scenie pragną uzyskać w swym życiu równowagę. Zajęcia teatralne dają im siłę $w$ życiu, pozwalają czuć się pewniej w społeczeństwie.

Obecne czasy i walka z dyskryminacją osób niepełnosprawnych sprawiły, że osoby z niepełnosprawnością są aktywne w społeczeństwie, są ambitne i pragną się rozwijać. Niemalże każdego dnia toczą walkę w własną niepełnosprawnością. Jednakże okazuje się, iż nadal w przestrzeni społecznej krążą wizje stereotypowych poglądów, zakorzenionych tak głęboko, iż nawet kampanie prowadzone na rzecz osób niepełnosprawnych nie są w stanie całkowicie ich usunąć.

Osoba niepełnosprawna ma takie samo prawo do życia w społeczeństwie, jak osoba pełnosprawna. Ma takie samo prawo do rozwoju. Teatr to miejsce, jak podkreślam, niezwykle, ale też miejsce dla każdego człowieka, który chce z perspektywy widza dostrzec prawdziwość sztuki i tego, który chce uczestniczyć w jej stworzeniu. Do tego jednak potrzeba dużych chęci, zaangażowania i talentu aktorskiego:

(...) teatr przez wiele lat był miejscem niedostępnym dla niepełnosprawnych. Integracja ludzi z różnych środowisk, przełamywanie wzajemnych uprzedzeń i odkrywanie wspólnych zainteresowań i pasji z powodzeniem może odbywać się poprzez teatr13.

Tu ludzi nie dzieli się na pełnosprawnych i niepełnosprawnych. Tu jest człowiek, ze swoimi przeżyciami i wrażliwością. Tu może odnieść tak wyczekiwany sukces, tu jest doceniany za to, co robi, za swe zaangażowanie w sztukę:

(...) występy na scenie to szansa na odniesienie sukcesu, tak rzadko dostępnego ludziom niepełnosprawnym. Akceptacja, oklaski, wzruszenie widowni. W tym akcie skupienia w sztuce, której twórcami są często ludzie odrzucani i niezrozumiani przez społeczeństwo, dokonuje się realizacja najważniejszego celu teatroterapii - rehabilitacji społecznej14.

\footnotetext{
13 Ibidem, s. 173.

14 Ibidem.
} 
Ewelina Romianowska - Teatr, media i ekranizacje...

Poprzez rehabilitację społeczną następuje włączenie osób niepełnosprawnych do społeczeństwa, w akcie zjednoczenia uczuć. Zaangażowanie, godziny prób, tworzenie dekoracji, przestrzeni, w której dokonuje się wcielenie $\mathrm{w}$ graną postać, tworzenie przestrzeni, która nie miałaby szansy zaistnienia, jak tylko w tym zjednoczeniu aktorów i widzów.

Można wymienić następujące funkcje teatroterapii:

- funkcja dydaktyczna (bliskoznaczna z funkcją wychowawczą) wychowawcze odziaływanie sztuki polega m.in. na tym, że sztuka, wzbogacając wewnętrzne życie człowieka, otwiera przed jego umysłem nowe wartości, a więc pogłębia nie tylko treści jego życia emocjonalnego, lecz działa też w kierunku kształcenia intelektu;

- funkcja hedonistyczna - sztuka przynosi odprężenie psychiczne, pozwala zapomnieć o troskach i smutkach życia;

- funkcja integracyjna - sztuka może być środkiem zintegrowania jednostki ze środowiskiem życia, zbiorowością, a więc środkiem uspołecznienia jednostki, uczestniczenia w przeżyciach i doświadczeniach innych ludzi;

- funkcja ludyczna - sztuka może służyć zabawie, zabawa zaś umożliwia realizowanie potrzeby swobodnej ekspresji osobowości;

- funkcja terapeutyczna - o swoistej terapii można mówić tylko wtedy, gdy sztuka rzeczywiście pomaga odzyskać równowagę psychiczną, częściowo przynajmniej rozładować i przezwyciężyć frustrację, depresję, konflikty wewnętrzne czy kompleksy ${ }^{15}$.

Wpływ teatroterapii na człowieka, na jego osobowość, na radzenie sobie z własnymi problemami jest niezwykle ważny. To dzięki relacji z innymi członkami grupy teatralnej wytwarza się taka więź, która pomaga osobie niepełnosprawnej przezwyciężyć wszelkie troski dnia codziennego, a jednocześnie kształci intelekt, rozwija umiejętności zabawy i wczuwania się w rolę. Niezwykle ważne jest w teatroterapii dą-

15 Ibidem. 
żenie do osiągnięcia równowagi psychicznej, przezwyciężenie kompleksów i wpływanie na wizerunek samego siebie.

Dostrzegła to także w 1992 r. aktorka Renata Jasińska. Postanowiła wówczas stworzyć eksperymentalny teatr, gdzie obok aktorów pełnosprawnych na scenie pojawią się aktorzy równie znakomici, jednakże będą to osoby niepełnosprawne. Budziło to wiele kontrowersji społecznych. Jednakże to jej nie zraziło, zafascynowanej teatrem Jerzego Grotowskiego - stworzyła niezwykły teatr, gdzie można dostrzec po dziś dzień integrację, akceptację i prawdziwą sztukę aktorską.

O uznaniu dla pracy twórczyni teatru i o niezwykłości sztuk teatralnych mówią znane osoby. Tomasz Domagała16:

Teatr Arka jest teatrem szczególnym. Został powołany ponad dwadzieścia lat temu. Od 2002 roku główną ideą teatru stało się hasło przywracania społeczeństwu osób niepełnosprawnych poprzez różne działania artystyczne. Idea ta realizuje się, na co dzień w symbiozie osób pełnosprawnych i niepełnosprawnych - a ściślej polega na stworzeniu zawodowego teatru integracyjnego, w którym osoby niepełnosprawne są równouprawnionymi członkami zespołu aktorskiego. Misją tego, co należy podkreślić, zawodowego teatru - obok przywracania społeczeństwu ludzi niepełnosprawnych - jest także zwracanie uwagi na ciężki los takich osób, na ich częstą dyskryminację i wykluczenie. Celem pobocznym jest $\mathrm{w}$ tym kontekście cierpliwa i metodyczna edukacja społeczeństwa w zakresie kontaktów i życia z ludźmi niepełnosprawnymi ${ }^{17}$.

To, co stało się za sprawą Renaty Jasienieckiej, pociągnęło za sobą w konsekwencji dostrzeżenie przez społeczeństwo, iż osoby niepełnosprawne mogą posiadać talent i są w stanie uzewnętrznić go za sprawą działań artystycznych w taki sam sposób, jak osoby pełnosprawne. W tym teatrze wszyscy aktorzy mają takie same prawa i równe obowiązki. Renata Jasińska podjęła ciężką walkę z dyskryminacją osób niepełnosprawnych przez społeczeństwo.

Dalej Tomasz Domagała mówi:

(...) instytucja to na mapie kulturalnej szczególna, gdyż jest ona jedynym ośrodkiem tego typu w Polsce. Dyrektor Renata Jasińska stała się realizować

\footnotetext{
16 Nie jest podana data oznaczenia cytatu przez Tomasza Domagałę.

17 http://teatrarka.pl/pl/text,48.html [dostęp: 29.12.2016].
} 
Ewelina Romianowska - Teatr, media i ekranizacje...

swoją misją dwutorowo. Za pomocą formy, w jakiej funkcjonuje jej teatr oraz za pomocą repertuaru. Przyczyną jej sukcesów na tym polu jest staranny dobór pozycji repertuarowych ${ }^{18}$.

Mladen Blaćić ${ }^{19}$ (krytyk teatralny działu kultury „Oslobodenje”) z Sarajewa twierdzi, iż:

(...) specyfika pracy tego nadzwyczajnego teatru przejawia się w projektach, w których razem, ramię w ramię, grają profesjonalni aktorzy, a także osoby niepełnosprawne, osoby wykluczone, które tak często spotykamy, ale tylko na marginesie życia społecznego. To dogłębne przenikanie nas samych, których uważamy za normalnych, i tych drugich, których widzieliśmy w teatrze. Przypomnijmy sobie chociażby twórczość Pipo del Bono. Polski teatr natomiast przekłada to na całkiem inny, niewyobrażalny poziom w kategoriach artystycznych i humanistycznych ${ }^{20}$.

Starania R. Jasińskiej są doceniane zarówno przez osoby, które na co dzień nie są związane z przestrzenią artystyczną, jak i takie, które na co dzień zajmują się przestrzenią teatralną. Potrafiła ona dostrzec, iż przestrzeń kulturalna wcale nie jest inną przestrzenią niż ta, w której żyją osoby niepełnosprawne. Te przestrzenie nachodzą na siebie, są nierozerwalne. Osobom niepełnosprawnym potrzebny jest udział w przestrzeni kulturalnej. Mają prawo do aktywności w tejże przestrzeni do rozwoju swych umiejętności czy to w sztuce teatralnej, czy plastycznej, a może też muzycznej. Tak, jak ta przestrzeń oddziałuje na nich, tak i one oddziałują na nią. Przestrzeń społeczna to przestrzeń, w jakiej żyje człowiek i nie można mu ograniczać świata kultury, bowiem to właśnie poprzez relacje, które tworzą się za pomocą świata kultury między osobami niepełnosprawnymi a pełnosprawny$\mathrm{mi}$, następuje ich szeroka integracja.

Poprzez tworzenie sztuk teatralnych osoby niepełnosprawne mogą przemówić na scenie we własnym imieniu. Tu nikt nie musi stawać w ich obronie, bowiem sami chcą pokazać, jak wiele potrafią zdziałać.

\footnotetext{
18 Ibidem.

${ }^{19} \mathrm{Nie}$ jest podana data oznaczenia cytatu przez Mladen Blaćić.

$20 \mathrm{http://teatrarka.pl/pl/text,48.html} \mathrm{[dostęp:} \mathrm{29.12.2016].}$
} 


\section{Innym przykładem teatru jest Blue Teapot Theatre:}

Blue Teapot Theatre jest profesjonalną grupą teatralną tworzoną przez 9 aktorów z niepełnosprawnością intelektualną. Przy Blue Teapot w 2010 r. powstała trzyletnia szkoła aktorska dla osób z niepełnosprawnością intelektualną (Performing Arts School), która umożliwia im uzyskanie certyfikatu Further Education nad Training Awards Council (FETAC) w zakresie sztuk performatywnych. Założeniem Blue Teapot jest stworzenie miejsca do rozwoju twórczej tożsamości osób z niepełnosprawnością intelektualną oraz zmiana społecznej świadomości dotyczącej osób z niepełnosprawnością intelektualną dzięki medium, jakie stanowi teatr. Osoby z niepełnosprawnością intelektualną dzięki swojemu talentowi i kreatywności mają zatem szansę mówienia we własnym imieniu ${ }^{21}$.

Na twórczość osób niepełnosprawnych należy patrzeć tak samo, jak na twórczość osób pełnosprawnych. Należy stworzyć odpowiednie warunki przyjęcia tejże twórczości przez społeczeństwo. Przestrzeń publiczna musi być gotowa, iż zobaczy na scenie niepełnosprawnego artystę, aktora, który dołoży zapewne wszelkich starań, by jego przekaz był profesjonalny. Jednak należy przede wszystkim stworzyć osobie niepełnosprawnej szansę zaistnienia w roli aktora, pokazania swych umiejętności. Należy zadać sobie pytanie:

(...) jak stworzyć odpowiednie warunki do spotkania z dziełem niepełnosprawnego intelektualnie artysty możliwie jak największej grupie odbiorców? Jest to zadanie niezwykle trudne. Wyjście z izolacji wymaga bowiem przełamywania wielu barier i ograniczeń tkwiących zarówno w środowisku społecznym, jak i w samych osobach niepełnosprawnych i ich najbliższym otoczeniu $^{22}$.

Coraz więcej miejsc kultury otwiera się na promocję dzieł niepełnosprawnych artystów, „środowiska osób niepełnosprawnych muszą jednak wyjść z propozycją ciekawą, profesjonalną, skoncentrowaną na walorach twórczości osób z niepełnosprawnością intelektualną, a nie

${ }^{21}$ http://www.blueteapot.ie/about-us [dostęp: 30.12.2016]; [za:] S. Pawlik, Sztuka jako sposób włączania osób z niepełnosprawnościq intelektualnq do społeczeństwa, „Interdyscyplinarne Konteksty Pedagogiki Specjalnej” 2015, nr 8, s. 69.

22 S. Pawlik, Sztuka jako sposób..., op. cit., s. 64. 
Ewelina Romianowska - Teatr, media i ekranizacje...

na samej niepełnosprawności"23. Dąży się do spoglądania na ową twórczość bardzo obiektywnie. Artyści nie chcą oceny swych dokonań przez pryzmat niepełnosprawności. Dążą do pokonania swoich słabości, do pokazania społeczeństwu sztuki, piękna działa artystycznego i wyjścia do otwartej przestrzeni społecznej składającej się zarówno z ludzi niepełnosprawnych, chorych, jak i zdrowych, pełnosprawnych, osób starszych i młodszych, osób, dla których twórczość teatralna nie jest obojętna.

\section{Udział mediów i przekaz ekranizacji filmowych apelujący o włączenie osób niepełnosprawnych intelektualnie do przestrzeni społecznej}

W tej części artykułu został przedstawiony udział mediów w walce z dyskryminacją osób niepełnosprawnych i poczynania w przełamywaniu stereotypów. Kampanie społeczne głoszone przez media mają różne cele, wyrażone na przykład hasłem „Niepełnosprawni intelektualnie mogą cię zarazić..., ale tylko pasją"24. Inna kampania przyjęła sobie za cel: „osoby z niepełnosprawnością intelektualną są takimi samymi ludźmi jak inni, zdolnymi do odczuwania emocji, osiągnięcia sukcesów sportowych i przełamywania własnych słabości”25. Realizacja wymienionych celów miała szeroki wymiar, chodziło o ukazanie nie tylko pasji, jakie posiadają osoby niepełnosprawne intelektualnie, ale także o pokazanie, iż właśnie te osoby mają takie same prawa i możliwości ich zaspokojenia, jak osoby pełnosprawne. Do realizacji celów kampanie wykorzystują następujące środki:

- materiały edukacyjne, filmy instruktażowe, ulotki, kalendarze,

- bilbordy i citylighty, akcje plakatowe w miejscach użyteczności publicznej,

\footnotetext{
23 Ibidem.

${ }^{24}$ S. Olszewski, K. Parys, M. Trojańska, Przestrzenie życia osób niepełnosprawnych, Kraków 2012, s. 43.

25 http://www.akcja-empatia.pl/2016/05/05/zdolnosc-do-odczuwania-emocji-iuczuc-kontakt-z-doznaniami-cielesnymi-a-empatia/ [dostęp: 29.12.2016].
} 
- kursy dla nauczycieli,

- radiowe i telewizyjne spoty reklamowe, reklama prasowa, internetowa,

- strony internetowe, stymulacje komputerowe,

- wystawy fotograficzne,

- akcje SMS-owe ${ }^{26}$.

Kampanie społeczne apelują do osób pełnosprawnych nie tylko w sprawie zwrócenia uwagi społecznej na pasje, zainteresowania osób niepełnosprawnych, ale także o zwrócenie uwagi na bariery architektoniczne, stanowiące przeszkody dla tychże osób. Chodzi tu m.in. o zamontowanie wind, ruchomych schodów w miejscach publicznych, aby wszelkimi sposobami zapewnić niepełnosprawnym dostęp m.in. do kultury.

W przeciągu kilkunastu ostatnich lat media otworzyły się szerzej na niepełnosprawność, ukazując różne rodzaje niepełnosprawności, wzywając do szeroko rozumianej integracji. Postąpił tak nie tylko teatr, jak pisałam wcześniej, zatrudniając osoby niepełnosprawne, przystosowując swoje budynki, widownie do potrzeb niepełnosprawnego widza. Integrację możemy także dostrzec w innych środkach masowego przekazu, jak np. telewizja. Tomasz Sahaj w 2013 roku pisał:

(...) w przeciągu zaledwie kilku ostatnich lat mass media - zwłaszcza telewizja

- szerzej otworzyły swoje podwoje na obecność osób niepełnosprawnych i użyczyły im swojej przestrzeni antenowej. Przeciętnego odbiorcę telewizyjnego zdziwić może widok człowieka dotkniętego chorobą lub kalectwem na ekranie telewizyjnym - szczególnie, jako prowadzącego program - a już zwłaszcza wtedy, gdy dysfunkcje ruchowe lub zmiany cielesne są dostrzegalne i wyraźnie widocznie ${ }^{27}$.

Niepełnosprawny prezenter telewizyjny może budzić wiele kontrowersji, jednak nie należy wykluczać osób niepełnosprawnych z takiej pracy. Telewizja pragnie to pokazać $\mathrm{w}$ jak najlepszych świetle, a tym

\footnotetext{
26 Ibidem, s. 44.

27 T. Sahaj, Niepełnosprawni i niepełnosprawność w mediach, Warszawa 2013,
} s. 20. 
Ewelina Romianowska - Teatr, media i ekranizacje...

samym propaguje otwarcie innych miejsc pracy dla niepełnosprawnego pracownika.

Jednakże należy podkreślić, iż media mogą często kreować błędny, a wręcz przerysowany obraz osoby niepełnosprawnej jako osoby biednej, samotnej, niekiedy też jako bohatera, który po podjęciu walki ze swoją niepełnosprawnością wygrywa ją np. poprzez podjęcie pracy. Bartosz A. Szpurek, jeżdżący na wózku inwalidzkim, a także autor broszurki „Niepełnosprawność w środkach społecznego przekazu”, mówi:

(...) „wizerunek niepełnosprawnego w mediach jest schematyczny i stereotypowy. Osoby niepełnosprawne najczęściej pokazuje się w dwóch skrajnych wymiarach: biednej, nieszczęśliwej jednostki lub bohatera - człowieka bezradnego, oczekującego pomocy, wsparcia drugiej osoby. Cierpiącego, samotnego i nieszczęśliwego. Materiały ukazujące historię osób ciężko chorych, kończy często prośba o pomoc, o wpłatę pieniędzy na operację, rehabilitację, zakup kosztownych lekarstw. Tego rodzaju prośby, apele utrwalają w społeczeństwie negatywny obraz osoby niepełnosprawnej. Czynią z niej żebraka, człowieka niepotrafiącego zadbać o siebie, przedstawiają go, jako jednostkę niezdolną do bycia samodzielnym (...). Drugi - najbardziej odpowiadający środkom społecznego przekazu ukazuje niepełnosprawnego, jako człowieka szczęśliwego, pełnego optymizmu. Kogoś, kto mimo swej niepełnosprawności odnosi wiele sukcesów, rozwija się, awansuje. Człowieka o wyjątkowych zdolnościach”28.

Jednak należy pamiętać, że media w znacznej mierze przyczyniły się do włączenia osób niepełnosprawnych do społeczeństwa poprzez głoszone kampanie. Media wielokrotnie wzywają do włączenia osób niepełnosprawnych do różnych aspektów życia codziennego. Zdarzają się jednak kampanie - mające na celu kwestie pomocowe, zbiórkę pieniędzy - które często pokazują osoby niepełnosprawne jako te, którym należy pomóc, które same sobie nie poradzą. W opisywanej przestrzeni społecznej są takie osoby, borykające się z niepełnosprawnością, którym kondycja zdrowotna nie pozwala na samodzielne funkcjonowanie, na aktywność w swojej przestrzeni społecznej, na podjęcie pracy, a przede wszystkim na leczenie. Nagłaśniane przez media zbiórki pieniężne na te osoby często są dla nich oknem na nową

28 Ibidem, s. 30, [za:] B. A. Szpurek, Niepełnosprawność w środkach społecznego przekazu, Leszno 2008, s. 9. 
rzeczywistość, taką, która chociaż w pewnym stopniu zapewni im godną egzystencję.

Temat niepełnosprawności na ekranie telewizyjnym prezentowany był w zależności od podejścia społecznego następująco:

- od roku 1945 do połowy lat 70. - temat rzadko podejmowany $\mathrm{w}$ mediach, postawy społeczeństwa negatywne i stereotypowe, znaczący wpływ czynników politycznych, a także niechęć artystów do podejmowania tematu z powodów etycznych i istnienia w kulturze swoistego tabu;

- od połowy lat 70. do przełomu roku 1989 - coraz częstsze próby podjęcia tematu, dostrzeżenie problemu, wpływ kultury Zachodu, sygnały zmiany wizerunku osób niepełnosprawnych w społeczeństwie i mediach ${ }^{29}$.

Jak widać, początki pokazywania niepełnosprawności za pomocą telewizji, mediów, produkcji ekranowych były trudne i w znacznej mierze uzależnione od społeczeństwa, które nie chciało poruszać głośno tematów niepełnosprawności, uznając, iż jest to temat tabu. Stopniowe przełamywanie barier narzuconych przez społeczeństwo było związane z narzucaniem zachodnich wzorów kulturowych, a tym samym przyczyniło się do zainteresowania niepełnosprawnością i stopniowego poruszania kwestii z nią związanych w mediach. Następnie można wyróżnić etapy:

- okres transformacji (dekada lat 90.) - z jednej strony często realizowane filmy o niepełnosprawnych, zazwyczaj ugruntowujące zakorzenione stereotypy i uprzedzenia, $\mathrm{z}$ drugiej - tendencje do rewolucyjnych zmian w tym względzie - Casus „Nienormalnych” Jacka Bławuta oraz jego naśladowców i kontynuatorów, dynamiczne pozytywne zmiany w światopoglądzie Polaków na temat niepełnosprawności;

- okres potransformacyjny (lata dwutysięczne) - kreowanie pozytywnego obrazu niepełnosprawnych $w$ mediach przy jednocze-

${ }^{29}$ W. Otto, Obrazy niepełnosprawności w polskim filmie, Poznań 2012, s. 11-12. 
Ewelina Romianowska - Teatr, media i ekranizacje...

snym, ale już mniej powszechnym w porównaniu z okresem wcześniejszym, zjawiskiem powielania stereotypów i obiegowych opinii, tendencje do zmiany postaw z negatywnych na pozytywne powolna ewolucja ${ }^{30}$. Powolna ewolucja doprowadziła do tego, iż obecnie zaakceptowano niepełnosprawność ukazaną w filmach, na telewizyjnych ekranach $\mathrm{w}$ perspektywach odnoszących się do kwestii społecznych, moralnych, medycznych, czy terapeutycznych.

Wiele filmów zagranicznych, które napłynęły do Polski, odznaczało się ogromną siłą przekazu, np. „Lot nad kukułczym gniazdem” (1975) Miloša Formana, „Piękny umysł” (2001) Rona Howarda, czy też „Motyl i Skafander" (2007) Juliana Schnabela ${ }^{31}$. Wymienione filmy miały na celu przełamanie bariery społecznej w spojrzeniu na niepełnosprawność, były odzwierciedleniem zapotrzebowania społecznego. Szybkie zmiany społeczne narzucały większe wymagania i eksponowanie problemów, a także życia osób niepełnosprawnych. Zaczęto dostrzegać, iż w społeczeństwie obok osób pełnosprawnych żyją, pracują, uczą się, są aktywne osoby niepełnosprawne. Doprowadziło to do sytuacji, w których reżyserzy:

(...) po pierwsze - swoimi filmami uświadamiali widzom istnienie obok nich osób niepełnosprawnych, po drugie - udowodniali, że osoby te potrafią dokonać rzeczy wielkich, po trzecie w końcu - ich ważnym celem społecznym stało się ugruntowanie $\mathrm{w}$ opinii publicznej przekonania, że człowiek niepełnosprawny jest jednostką równie interesującą i wartościową jak członkowie zdrowej części społeczeństwa32.

Autorzy filmowych ekranizacji starali się przez lata przełamać stereotypy dotyczące osób niepełnosprawnych, dążyli do całkowitego włączenia ich do świata, w którym żyli, a który tak dalece ich usunął, usunął ich aktywność. Dziś osoby te mogą się czuć pełnowartościowymi i pełnosprawnymi członkami społeczeństwa. Przełamywanie barier, ukazywanie piękna istoty ludzkiej to trudna misja, jednak

\footnotetext{
30 Ibidem, s. 12.

31 Ibidem, s. 13.

32 Ibidem, s. 23.
} 
wielu reżyserów, aktorów, nie wystraszyło się podjęcia tego zadania. Obecnie na szklanych ekranach możemy zobaczyć grające w filmach osoby o różnych niepełnosprawnościach. Jest wielu znakomitych aktorów, u których niepełnosprawność nie wyklucza własnego rozwoju i udziału w przestrzeni społecznej. Tu należy przywołać postać Piotra Swenda grającego w serialu „Klan”, emitowanym w TVP1. Rozwija on swoje pasje, zainteresowania, a tym samym pragnie pokazać, iż zespół Downa wcale nie musi skazać człowieka na wykluczenie z udziału w społeczeństwie. Innym znakomitym aktorem jest Pablo Pineda, który ma także zespół Downa.

Pablo Pineda ma 39 lat, jest pedagogiem, absolwentem uniwersytetu w Maladze. Pracuje w urzędzie miasta i zajmuje się problemami osób niepełnosprawnych. Bywa też aktorem - za główną rolę w filmie „Yo, Tambien” („Ja też!”) w 2009 roku otrzymał nagrodę na festiwalu w San Sebastian ${ }^{33}$.

\section{Zakończenie}

Można powiedzieć, iż bez zaangażowania dyrektorów teatrów akceptujących niepełnosprawnych aktorów na scenie, bez mediów, bez produkcji filmowych ukazujących niepełnosprawność życie społeczeństwa polskiego, nie uległoby zmianie. Bowiem wszystkie te czynniki miały ogromny wpływ na wiedzę przeciętnego człowieka o niepełnosprawnościach, w tym o niepełnosprawności intelektualnej.

Przyrost wiedzy na temat niepełnosprawności w polskim społeczeństwie sprawił, że w refleksji filmowej na ten temat pojawiły się wątki i motywy wcześniej mało raczej znane. Reżyserzy stawiali się w roli pośrednika próbującego opisać świat oczami osoby niepełnosprawnej, by zgłębić w ten sposób tajemnice jej egzystencji i przybliżyć tę prawdę widzowi ${ }^{34}$.

Celowe stało się wówczas ukazanie społeczeństwu uczuć osób niepełnosprawnych, a także ich życia - czy to poprzez granie w sztukach teatralnych, czy też w występach w telewizji czy w kampaniach rekla-

33 http://www.newsweek.pl/nauka/zespol-downa-lek-pablo-pineda-newsweekpl,artykuly,270406,1.html [dostęp: 30.12.2016].

34 W. Otto, Obrazy niepełnosprawności..., op. cit., s. 33. 
Ewelina Romianowska - Teatr, media i ekranizacje...

mowych - ukazanie problemów, z jakimi się borykają na co dzień, barier, jakie stwarzają im osoby pełnosprawne, ich stereotypowych podejść. Świat widziany oczami osób niepełnosprawnych to świat bardzo podobny do świata widzianego oczami osób pełnosprawnych jeśli zaakceptujemy ich udział w życiu społecznym.

\section{Bibliografia:}

Andrzejczuk A., Terapeutyczne aspekty aktywności teatralnej osób z niepełnosprawnością, [w:] M. Gliniecki, L. Maksymowicz (red.), Teatr. Terapia Edukacja - Asertywność - Twórczość - Rozwój, Słupski Ośrodek Kultury \& Teatr STOP, Słupsk 2004.

Bliska M., Golanko R., Teatroterapia jako jedna z form rewalidacji osób niepełnosprawnych intelektualnie, [w:] J. Bergier, Z. Kubiańska (red.), Kultura i rekreacja ruchowa $w$ integracji osób niepełnosprawnych, Państwowa Wyższa Szkoła Zawodowa w Białej Podlaskiej, Biała Podlaska 2006.

Olszewski S., Parys K., Trojańska M., Przestrzenie życia osób niepełnosprawnych, Wydawnictwo Naukowe UP, Kraków 2012.

Otto W., Obrazy niepełnosprawności w polskim filmie, Wydawnictwo Naukowe Uniwersytetu im. Adama Mickiewicza w Poznaniu, Poznań 2012.

Parys K., Przestrzeń społeczna, [w:] S. Olszewski, K. Parys, M. Trojańska, Przestrzenie życia osób z niepełnosprawnością, Wydawnictwo Naukowe UP, Kraków 2012.

Pawlik S., Sztuka jako sposób włączania osób z niepełnosprawnościq intelektualnq do społeczeństwa, „Interdyscyplinarne Konteksty Pedagogiki Specjalnej" 2015, nr 8.

Piasecka A., Terapeutyczna funkcja teatru. Między teoriq a praktyka, [w:] I. Jajte (red.), Terapia i teatr. Wokół problematyki teatru ludzi niepełnosprawnych, Polski Ośrodek Sztuki, Łódź 1996.

Rudek I., Podstawy wobec osób niepełnosprawnych jako wyznacznik działań integracyjnych, [w:] Z. Kazanowski, D. Osik-Chudowolska (red.), Integracja osób niepełnosprawnych $w$ edukacji i interakcjach społecznych, Wydawnictwo Uniwersytetu Marii Curie-Skłodowskiej, Lublin 2003.

Sahaj T., Niepełnosprawni i niepełnosprawność w mediach, Instytut Rozwoju Służb Społecznych, Warszawa 2013. 
Stańko M., Arteterapia, mechanizmy działania z perspektywy neuropsychologii, „Psychoterapia” 2009, nr 2(149).

Stefańska A., Teatroterapia jako metoda kształtowania poczucia godności u osób niepetnosprawnych intelektualnie, Uniwersytet im. Adama Mickiewicza w Poznaniu, Poznań 2012.

Szpurek B. A., Niepełnosprawność w środkach społecznego przekazu, Wyższa Szkoła Humanistyczna, Leszno 2008.

\section{Netografia:}

http://teatrarka.pl/pl/text,48.html [dostęp: 29.12.2016].

http://www.akcja-empatia.pl/2016/05/05/zdolnosc-do-odczuwaniaemocji-i-uczuc-kontakt-z-doznaniami-cielesnymi-a-empatia/ [dostęp: 29.12.2016].

http://www.blueteapot.ie/about-us [dostęp: 30.12.2016].

http://www.duszki.pl/poogladaj_poczytaj/swiadectwa/artykul_o_gosi.html [dostęp: 20.12.2016].

http://www.newsweek.pl/nauka/zespol-downa-lek-pablo-pinedanewsweek-pl,artykuly,270406,1.html [dostęp: 30.12.2016]. 